$$
\text { studie }
$$





\title{
Překládání potenciální literatury a potenciální vlastnosti překladu
}

\author{
Anna Šmídová
}

\begin{abstract}
Translation of Potential Literature and Potential Properties of Translation ${ }^{1}$

This study aims to open a reflection on the problems connected to the translation of potential literature. Potential literature is a term used in the context of the Workshop of Potential Literature (OuLiPo), a French experimental group established in 1960 in order to interconnect literature and mathematics. It is characteristic of OuLiPo to create texts with the aid of a "contrainte", a mostly formal restriction applied during the creative process, limiting the set of potential outcomes. These specific creative methods bring a higher level of difficulty for the translator and raise the question of "untranslatability". The paper proposes several alternative concepts of a "translation" in order to get past this idea of impossibility. Similar properties of both potential literature and translation as creative processes are also discussed. This brings new light on their connection and enables us to characterize a translator of potential literature as one of the authors of the text.
\end{abstract}

\section{KEYWORDS}

OuLiPo, Ouvroir de Littérature Potentielle, Workshop of potential literature, translation, OuTransPo, Workshop of potential translation.

\section{KLÍčOVÁ SLOVA}

OuLiPo, Ouvroir de Littérature Potentielle, Dílna potenciální literatury, překlad, OuTransPo, Dílna potenciálního překladu.

1) Překlad $z$ angličtiny a francouzštiny: autorka, překlad z němčiny: Vincenc Bouček. 


\section{Úvod - Dílna potenciální literatury}

Netypické členění textu, kostrbatě znějící věty, někdy i nesmyslně působící odstavce: tvůrčí postupy Dílny potenciální literatury, OuLiPo, představují jednu z vyhraněných literárních poloh. Francouzské experimentální uskupení Ouvroir

(1) de Littérature Potentielle, založené v roce 1960 jako odnož Kolegia ,Patafyziky', si stanovilo za záměr propojovat literaturu s matematikou a tento závazek plní dodnes. Jakkoli kuriózní se koncepce OuLiPo mohou zdát, daly vzniknout inovativnímu pohledu na literární text a samotná Dílna se stala mezinárodním pojmem. Pojmem, který s časem nezešedl, ale naopak neustále nabírá celou paletu různorodých odstínů.

Již od počátečních let bylo OuLiPo pluridisciplinárně orientovaným uskupením. Impulz k jeho založení vzešel od matematika, chemika a bývalého dadaistického básníka Françoise Le Lionnaise, který ke své myšlence přizval dlouholetého prrítele, spisovatele, encyklopedistu a milovníka matematiky, Raymonda Queneaua. Seskupení prvních členů vypovídalo o záměru nahlížet na literaturu ve zcela nové perspektivě: Claude Berge byl specialistou kombinatorické analýzy, Albert-Marie Schmidt znalcem tzv. vědecké poezie, Paul Braffort pracoval v oblasti jaderné energie (DE BARY 2014: 16). Mezi další osobnosti spojované s počátky OuLiPo patří Jean Lescure, Noël Arnaud, Jacques Duchateau, Emmanuel Peillet (pod pseudonymem Latis), Jacques Bens a Jean Queval. V roce 1962 se připojil i Marcel Duchamp, k zahraničním členům se řadil mj. spisovatel Italo Calvino. ${ }^{2}$

Popularita, které se Dílně během několika desetiletí jejího působení dostalo, podnítila tisíce lidí k vlastní experimentální tvorbě. Přinesla s sebou však i otázku toho, jak tzv. potenciální literaturu překládat a zda o něčem takovém vưbec uvažovat. To, že o něčem podobném uvažovat lze, je zřejmé už z toho důvodu, že tyto překlady existují. Pokusím se proto v následujících odstavcích přiblížit, jakým zpo̊sobem můžeme na překlad potenciální literatury nahližet a v jakém vztahu překlad vůči potenciální literatuře stojí. Tyto reflexe by nicméně nebyly úplné bez předešlého připomenutí základních tvůrčích principů, se kterými OuLiPo pracuje.

12) Soupis všech členů je dostupný na oficiálních webových stránkách skupiny www.oulipo.net. 


\section{Pečlivě vymezený prostor pro hru}

Vrat’me se na chvíli do úplných počátků francouzské Dílny. Tvorba nebyla pro členy OuLiPo, přinejmenším během prvních setkání, hlavním cílem. Dokazuje to skutečnost, že na prvních schůzkách byl zájem věnován především studiu již existujících textů. Hovoříme zde o tzv. analytických aktivitách OuLiPo, pojmenovávaných jako „Anoulipism“ (LE LIONNAIS 1973: 18). Členové Dílny v tomto kontextu zavedli označení „pre-oulipista“ (DE BARY 2014: 18), jinými slovy autor, který již v minulosti používal postupy, které Dílna definovala jako postupy generující potenciální literaturu. Tím jsou myšleny určité (nejenom) formální restrikce, jejichž formulování předchází tvorbě - typicky třeba podoba sonetu nebo alexandrinu. Pozornost byla orientována na starší autory, kteří byli v tomto směru nějakým způsobem zvláštní a neobvyklí. Pokud bychom nicméně měli být důslední, došli bychom k závěru, že na literární tvorbu celkově je možné nahlížet jako na tvorbu vycházející ve své podstatě z určité restrikce. Pravidla versifikace, kompozice, dějové linie a dalších prvků jsou nedílnou součástí veškerých textů i divadelních her. OuLiPo si stanovilo úkol vyžadující mravenčí úsilí: definovat co možná nejširší škálu těchto pravidel a restrikcí skrz naskrz časem i literárními žánry. A to s obzvláštní fascinací pro vše, co se může jevit kuriózní, až podivínské.

V další fázi se členové OuLiPo pustili do otevírání nových, předchůdci neprobádaných cest. Po studiu starších kanonických textů se tak do popředí jejich zájmu dostalo přepisování těchto děl a také vytváření děl vlastních. Od analytické činnosti se zde dostáváme k činnosti syntetické, tedy k „Synthoulipism“ (LE LIONNAIS 1973: 18). Všemožné metody (objevené v již existujících textech nebo formulované nově) byly zahrnuty pod zastřešující pojem contrainte ${ }^{3}$. Contrainte neboli zadání můžeme charakterizovat jako koncepci určující, jakým způsobem text musí, či nesmí být utvořen. Definuje tak množinu potenciálních možností toho, jak bude výtvor vypadat. Jako typický přílad poslouží jedno z prvních zadání využívaných při přepisování kanonických děl, tzv. metoda „s + 7“. Její princip spočívá v nahrazení každého substantiva již existujícího textu sedmým po něm následujícím heslem v libovolně zvoleném slovníku. Možné jsou i varianty s jinými slovními druhy a s jiným číslem.

3) Za nejvhodnější český překlad považuji „zadání“ (případně „tvưrčí“ či „restriktivní zadání"), přestože sémanticky francouzské „contrainte“ nepřekrývá zcela. 


\section{Tvorba na základě zadání}

Zadání je v přímé souvislosti s myšlenkou potenciality a slouží jako mentální koncepce, která získává formu skrze realizaci v textu. $Z$ tohoto hlediska můžeme říci, že pro existenci zadání není literární tvorba nutná: „metoda dostačuje sama sobě,“ jak upozorňuje Le Lionnais (OULIPO a BENS 2005: 88). Současně by však zadání, bez existence jemu odpovídajícího textu, nedostalo prostor se projevit a jeho potencialita by zůstala neobjevena. Kromě toho zásadním pohonem pro konkrétní příklad realizace zadání je jednoduše autorova radost: „př́klad je potěšení, které si dopřáváme navíc - a který dopřáváme čtenáři“ (OULIPO a BENS 2005: ibid.). Výhradně koncepční pojetí by členy Dílny nemohlo dlouho naplňovat, nebot' oulipisté usilují o co největší možné rozvinutí pole možností tvorby a obrazně směřují k jejímu vyčerpání. Patafyzicky usilují o „naplnění všech potencialit“ skrze hru s jazykem a současně jsou si vědomi nemožnosti toho dosáhnout (BRAY 2016: 42).

Pojem zadání nebyl během prvních setkání skupiny explicitně využíván (řeč byla spíše o struktuře či metodě; LESCURE 1973: 27), nicméně poměrně záhy se stal emblematických rysem OuLiPo a přispěl k širšímu povědomí o celé skupině. Katalogizace nejrůznějších typů zadání představuje klíčovou aktivitu Dílny. Dlouhý seznam, z něhož výběr je k nahlédnutí na webových stránkách stále fungujícího uskupení, nabízí zadání jednotlivá i mnohonásobná, snadno rozpoznatelná v textu až neviditelná, snadná na provedení i velmi obtížná. ${ }^{4}$ Pro ilustraci a lepší pochopení se podívejme na několik příkladů.

Kromě metody „s + 7“, navržené Jeanem Lescurem, je dalším z typických zadání „lipogram“, tj. sepsání textu bez použití předem zvoleného písmene či písmen. Může se jednat jak o samohlásky, tak o souhlásky, podmínkou však je, aby slova nebyla upravována a aby nebyla nijak výrazně snížena srozumitelnost a soudržnost celku. Jako mistr tohoto oboru proslul Georges Perec svým třísetstránkovým románem Zmizení, který byl napsán bez jediné hlásky „e“.5 $\mathrm{Z}$ dalších typů zadání zmiňme nap̌r. „palindrom“, tj. slovo či text, který má stejnou podobu při čtení zleva doprava i zprava doleva, dále „poème de métro“, což je báseň napsaná v metru, jejíž tvorba je omezená časem přejezdu z jedné

4) Čtenář, který se pro jazykovou bariéru nebude moci do soupisu všech vynalézavých i zákeřných typů zadání začíst, určitě ocení český slovník základních pojmů OuLiPo, který pro říjnové číslo měsíčníku Plav z roku 2006 vypracovali Michaela Otterová a Josef Šlerka.

5) Na celistvý český překlad román La Disparition (1969) zatím stále čeká, nicméně zdařilé české úryvky jsou k nalezení ve zmíněném čísle Plav (2006). Postaraly se o ně překladatelky Tereza Maòhalová a Michaela Otterová. 
stanice do druhé. Jiné zaujme „hai-kaizace“, ${ }^{6}$ která spočívá ve zkrácení původní básně pouze na koncové verše, čímž vzniká krátký útvar blízký japonskému haiku, nebo „abécédaire“ tedy text, ve kterém po sobě následující slova začínající na písmena dle pořadí abecedy. Vtipné hřičky vznikají procesem „locurime“, který nahrazuje určitá slova př́sloví či aforizmu jinými, která se s původními rýmují. Specifickým úkazem je tzv. „clinamen“ neboli záměrné porušení zadání, které má za cíl narušit jinak přesnou strukturu a zamezit rigiditě, skýtá však i prostor pro vtip.

Matematika hraje $\mathrm{v}$ zadáních podstatnou roli, ač to pro laiky nemusí být na první pohled zřejmé. Typickým příkladem je 41 sonnets irrationnels (41 iracionálních sonetů) Jacquese Bense z roku 1965. Básně respektují formu sonetu co do celkového počtu veršů, nicméně počet veršů ve strofě je určen číslem pí: strofy o 3, 1, 4, 1 a 5 verších (tedy 3,1415). Takto utvořená báseň disponuje vlastním charakteristickým rytmem (DE BARY 2014: 37). Uplatnění komplexních matematických principů je základem také např́klad pro zadání „morale élémentaire“ definované Raymondem Queneauem nebo pro „Mathewsovův algoritmus“ Harryho Mathewse. Obě metody jsou blíže popsány v kolektivní publikaci Atlas potenciální literatury (OULIPO 1988).

OuLiPo rovněž přichází s pojmem kombinatorické literatury. Poprvé jej použil zakladatel Dílny François Le Lionnais v doslovu ke Queneauovým Cent mille milliards de poèmes (Sto tisíc miliard básní) z roku 1961. Queneau svými 10 krát 14 verši, které mezi sebou čtenář může libovolně kombinovat, nabízí podklad pro celkem $10^{14}$ odlišných sonetů, které vystačí na 190,258,751 let četby. De Bary používá v kontextu této sbírky označení „exponenciální poezie“ a doplňuje, že podobné snahy existovaly například už v sedmnáctém století (DE BARY 2014: 26). Kombinatorické principy jsou také podkladem sbírky $\in$ Jacquese Roubauda z roku 1967 nebo románu Georgese Pereca La Vie mode d'emploi ${ }^{7}$ (1978). Zde autor aplikuje princip latinského čtverce, který umožňuje volně permutovat sérii elementů vyprávění (např. charakter postav a jejich chování) (DE BARY 2014: 27). Již od počátků svého působení rozvíjelo OuLiPo své iniciativy i v oblasti generativní literatury, postupně od nich ale upustilo ve prospěch ALAMO, ${ }^{8}$ Ateliéru literatury asistované matematikou a počítači, založeného v roce 1981.

6) Překlad z francouzského haï-kaïsation podle článku Jiřího Konůpka (KONŮPEK 1966: 173).

7) V češtině vyšlo v překladu Kateřiny Vinšové pod názvem Život - návod k použití, Praha: Mladá fronta, 1998.

8) Atelier de Littérature Assistée par la Mathématique et les Ordinateurs. 
Vnímáme-li literární text jako projev kreativní svobody, mohli bychom si položit otázku, zda zadání nepředstavuje pro autora omezení jeho osobní tvořivé invence. Oliver Bray uvádí, že pro OuLiPo má koncepce zadání funkci zcela opačnou: „Restriktivní zadání, komplexní struktury a často vědecký přístup skupiny jsou výsledkem oulipistické filozofie, podle které je jednání za takovýchto podmínek osvobozující [...]“ (BRAY 2016: 41). Tvořivý proces se podle něj stává pro spisovatele hrou, ve které zadání představuje umělcovu múzu. De Bary dokonce spatřuje v rozvinutí práce se zadáním přínos pro celé literární pole: „[...] oulipisté skutečně dali vzniknout dílům se specifickými funkcemi. Zadání s sebou přineslo otázky týkající se jazyka, literatury a jejich norem. Také je uvedlo do praxe. Otevírá nové narativní dynamiky. Umožňuje napojení na poetickou tradici tím, že ji přepracovává. Otevírá možnosti literatury a zkoumá její limity“ (DE BARY 2014: 3).

\section{Potenciální literatura za jazykovými hranicemi}

Velký úspěch sofistikovaných literárně-jazykových her roznesl myšlenky OuLiPo do řady dalších zemí a s dnešním využitím internetu už v podstatě i daleko za jakékoli geografické limity. Ani pro českého čtenáře se nejedná o zcela nový pojem. Dílna byla u nás uvedena do povědomí v roce 1966 (tj. šest let po jejím vzniku) v revui Světová literatura, kde ji představil Jiří Konůpek v článku věnovaném jednomu ze zakladatelů dílny, Raymondu Queneauovi. V nám bližším datu se jí dostalo patřičného prostoru v již zmíněném čísle měsíčníku Plav z roku 2006. V českém prostředí možná myšlenky potenciality nezakořenily s takovou silou, jako tomu bylo ve Francii, ale i u nás se najdou autoři, kteří v obdobných jazykových hrách našli zálibu. Zmiňme alespoň jednoslabičnou pohádku Chlap, děd, vnuk, pes a hrob (1998, původně z roku 1960) Jana Wericha nebo knihu jazykových her a rébusů pro děti Co se slovy všechno poví (1964) Josefa Hiršala a Bohumily Grögerové. ${ }^{9}$ Za oulipistické počiny u nás bychom mohli považovat také české překlady potenciální literatury. Je zcela zřejmé, že překlad výtvorů skupiny OuLiPo není disciplínou pro každého, proto i českých překladatelů, kteří by se do podobných kousků pouštěli, je skromný počet. Proč však vnímat pře-

9) Oba citované texty používají quazioulipistické principy, nicméně bez př́ímé návaznosti na OuLiPo. 
klad potenciální literatury jakožto akrobatický kousek à la OuLiPo? Odpověd’ si zaslouží širší uvedení.

\section{Když je řeč o literárním překladu...}

Zamýšlíme-li se nad překladem potenciální literatury, zastavme se chvíli nad obecnými vlastnostmi samotného literárního překladu. Literární text je charakteristický převládající estetickou funkcí, která vyžaduje od čtenáře jistou míru vnímavosti k detailům a nuancím. Skrze tyto prvky je formováno to, co označujeme jako autorský styl a originalitu. Jaký přístup k těmto specifikům je možné považovat za vhodný v procesu překladu? Jonathan Baillehache v článku věnovaném problematice překládání literatury zadáni ${ }^{10}$ odkazuje k myšlenkám Antoina Bermana (BAILLEHACHE 2016, BERMAN 1999). Ten navrhuje perspektivu, ve které není estetickým záměrem translátu literaturu imitovat nebo transponovat, ale projevit ji, vytvořit její komentár̆, který odhaluje její dosud neznámé aspekty (BAILLEHACHE 2016: 896). Podle Bermana je překlad ve vztahu dialogu k výchozímu textu a skrze proces poetické tvorby přináší novou kritickou perspektivu (BAILLEHACHE 2016: 898). Jeho originalita je dialogem s originalitou předlohy, ne jejím nahrazením (BAILLEHACHE 2016: 903).

Vztáhneme-li tuto perspektivu k potenciální literatuře, jak uvádí Baillehache, mohou být specifické prvky textu vzniklého na základě zadání odhaleny skrze komentář, kterým je překlad (BAILLEHACHE 2016: 894). Zároveň nám pohled na translát jako na hypertextový komentář originálu může sloužit jako jeden $\mathrm{z}$ argumentů pro oproštění se od konzervativního přístupu, jenž klade důraz na výchozí text a na tzv. ekvivalenci. Podporuje rovněž vnímání (literárního) překladu jako tvůrčího procesu. Důraz na tvořivost jako na jednu z důležitých strategií $\mathrm{k}$ dosažení adekvátního cílového textu je charakteristický pro přístup řady translatologů funkcionalistického zaměření, mezi jinými pro Christiane Nordovou, Paula Kußmaula, Dionýze Ďurišina nebo Zbyňka Fišera.

10) Označení „literatura zadání“ je v této studii využíváno jako synonymum „potenciální literatury“, tedy literárních textů, které vznikají na základě restriktivního zadání dle pojetí OuLiPo. 


\section{Překlad, přepis, transkreace}

Je patrné, že literární překlad s sebou přináší specifické vymezení vztahu mezi výchozím a cílovým textem. Hovoříme-li o překladu literatury potenciální, musíme vzít na vědomí také to, že oulipistický text je tvořen na základě zadání (formální restrikce) a jeho základním stavebním materiálem je jazyk (kulturně podmíněná restrikce). Vyvstává proto otázka, zda lze i v tomto případě označení „překlad“ považovat za odpovídající. Někteří by v kontextu určitých textů OuLiPo mohli hovořit o „nepřeložitelnosti“. ${ }^{11}$ Tyto obavy nicméně specialisté na překlad potenciální literatury skupiny OuTransPo (Ouvroir de Traduction Potentielle) nesdílejí: „Jakže? Nepřeložitelné? Nepřeložitelné nepřekládáme, protože neexistuje nic, co bychom mohli za nepřeložitelné označit. A pokud přeci existuje, pak je třeba skoncovat s tím, že daný text nikdo nepřekládá" (OuTransPo 2016). ${ }^{12}$ Pokud bychom nicméně byli toho názoru, že označení „překlad“ není v naší oblasti úplně přiléhavé, určitě by se namísto úplného zamítnutí myšlenky přenosu hodilo uvažovat o alternativních koncepcích tohoto pojmu. Valentina Rădulescuová využívá ve své studii rumunské, italské a anglické verze Exercices de style, průkopnického textu Dílny z pera Raymonda Queneaua, termíny „variace“ a „pře-psaní"13 (RĂDULESCU 2017: 41). Uvedené pojmy bohužel podrobněji nespecifikuje, nicméně užívá jich pro zdưraznění skutečnosti, že má-li si cílový text zachovat vlastnosti a funkce textu výchozího (v př́padě, že výchozí text je psaný na základě zadání), mohou se obsah a forma i výrazně vzdálit od cizojazyčné předlohy.

Problematice alternativní koncepce překladu se věnuje také Nina Sattler-Hovdarová v publikaci Translation - Transkreation: vom Über-Setzen zum Über-Texten. Využívá zde pojem „transkreace“, který opisuje jako „přetextování“ (SATTLER-HOVDAR 2016: 19). Transkreace, jak název naznačuje, v sobě zahrnuje přenos z jednoho jazyka do druhého (Translation) a současně i přepracování a adaptování v cílovém jazyce (Kreation). Kreativita by v rámci tohoto pojmu neměla být vnímána jako vnášející nepřesnost, naopak: přesnost je základním

11) Zatímco Perecova La Disparition (1969) se jako nepřeložitelná neprokázala (mezi cizojazyčnými verzemi se mj. najdou i japonská a turecká), její negativní forma v podobě románu Les Revenentes (1972), ve kterém je naopak hláska „“"jedinou použitou samohláskou, již představuje překladatelskou výzvu o mnoho řádů vyšší. I přesto však se tento román dočkal své německé verze Dee Weedergenger (2003, překl. Peter Ronge), která si do určité míry, koneckonců stejně jako originál, napomáhá metodou fonetického přepisu.

12) Členové této variace Ou-X-Po (podobných variací vznikla mimochodem celá řada, literaturu v názvu stačilo vyměnit za jinou disciplínu) jsou také autory cenných úvah o problematice, ve které se pohybujeme, a ještě o nich bude zmínka.

13) V originále jako „(ré)écriture“ (écriture - psaní), tedy současně jako psaní i přepisování. 
předpokladem transkreace (SATTLER-HOVDAR 2016: 19). Pečlivě promyšleného zpracování je překladatel schopen díky dostatečnému rozvinutí interkulturní sensibility, což se jeví jako nezbytně nutné: „Transkreativní textař musí být obratný jak ve výchozím jazyce, tak v cílovém, a musí být schopen myslet stejně jako př́ijemce daného sdělení." (SATTLER-HOVDAR 2016: 20). Sattler-Hovdarová vztahuje tento přístup především $\mathrm{k}$ oblastem marketingu, tedy $\mathrm{k}$ reklamě a dalším typům textů, které mají vliv na obchodní značku (SATTLER-HOVDAR 2016: 20).

Kreativní přístup překladatele je při práci s literárním textem nezbytný, v kontextu potenciální literatury pak naprosto nutný. V překladech textů OuLiPo představuje tvořivost běžně klíčový prvek, který je nositelem hlavní ideje sdělení. Jako př́klad úspěšného kreativního převodu textu potenciální literatury do českého prostředí zmiňme Stylistická cvičení, která na základě francouzského originálu Raymonda Queneaua vytvořil překladatel a autor Patrik Ouředník, čímž předvedl čtenářům paletu překladatelské tvořivosti par excellence. ${ }^{14}$ Pojem transkreace i pojmy variace a prepis nám mohou být nápomocny v získání konstruktivnějšího úhlu pohledu na překlad potenciální literatury, než je přesvědčení o tzv. nepřeložitelnosti. Představa nepřeložitelnosti se rozpustí v obrovském množství hypotetických podob, kterých cílový text může nabýt ve chvíli, kdy si připustíme, že lze upustit od touhy po „identičnosti“ a otevřít se myšlence „jiné“, avšak stejně funkční verze textu.

\section{Podobné vlastnosti - restrikce a potencialita}

Je zajímavé, že ve své podstatě má překlad jako tvůrčí proces s potenciální literaturou mnoho společného. Jak uvádí Baillehache, překlad je také svým způsobem typem tvorby na základě restriktivního zadání (BAILLEHACHE 2016: 894). Pablo Martín Ruiz v tomto kontextu uvádí, že během překládání

14) Jazykově-kulturní hříčka Exercices de Style (1947) spočivající v devadesáti devíti opakováních téže příhody v jiném formálním uchopení našla obdobu již ve více než tř̌iceti jazycích. Český překlad je dokladem toho, že snaha přibližit se originálu (potenciální literatury) může vést k podobě, která se na první pohled jeví jako výrazně odlišná. Pozorný čtenář však jistě zaznamenal, že překladatel Patrik Ouředník záměrně upravil jednotlivé tvưrčí postupy uplatněné v originálu tak, aby byly v českém prostředí stejně literárně působivé, jako jsou pro francouzského čtenáŕe ty původní. Stejná př́hoda se tak metamorfuje například z francouzské ódy na českou baladu nebo z dưrazu na italianismy na hru s germanismy. Současně lze říci, že překlad Exercices de Style vyžaduje tvưrčí invenci na úrovni autorské a že Patrik Ouředník tento aspekt úspěšně naplnil. Jeho smysl pro originalitu, schopnost hry s jazykem a široká slovní zásoba ho právoplatně staví po bok Raymonda Queneaua. 
vzniká nový text, jehož restriktivním zadáním je výchozí text v cizím jazyce (RUIZ 2016: 920). Jedná se podle něj konkrétně o dvě dílčí zadání: zachování obsahu a zachování zvuku (formy) (RUIZ 2016: 921). Zároveň však podotýká, že je třeba uvědomit si významný rozdíl mezi zadáními, se kterými operuje OuLiPo a která jsou zvolena svobodně, a zadáními (restrikcemi), která se týkají

(1) překladu a která je překladatel nucen akceptovat bez možnosti výběru (RUIZ 2016: 921). Rovněž upozorňuje, že podle Jacquese Roubauda text psaný na základě zadání odkazuje k zadání, což v případě překladu knihy neplatí: ta neodkazuje k restrikci zadání, ale k výchozímu textu (RUIZ 2016: 923). V každém případě, nahlížíme-li na překlad jako na druh restriktivní tvorby, pak je překlad potenciální literatury výzvou zdvojnásobenou, jak zmiňuje Rădulescuová (RĂDULESCU 2017: 41).

Stejně jako na překlad může být nahlíženo jako na určitý typ potenciální tvorby, na literaturu zadání může být nahlíženo jako na svého druhu překlad (BAILLEHACHE 2016: 894). Baillehache podotýká, že tento pohled nachází podporu v některých pracích, které členové OuLiPo prezentovali v Atlase potenciální literatury z roku 1981. Třicetistránková část pod názvem Trans je věnována automatickým transformacím textů: homofonickému překladu, homosyntaxi, překladu s modifikací literárního žánru, translexikálnímu překladu nebo také metodě „s + 7“ (BAILLEHACHE 2016: 894). Jedná se zde o překlad v rámci jednoho jazyka, tzv. intralingvální překlad. Jak uvádí Ruiz, jakýkoli oulipistický text může být viděn jako překlad neboli přepis jiné (hypotetické) knihy, která je v podstatě stejnou knihou napsanou bez zadání (RUIZ 2016: 922). Toto platí především u zadání, která mají charakter textových transformací - jako výchozí text si můžeme například zvolit Máchův Máj a metodou hai-kaizace vytvořit jeho tzv. translát. Nicméně o něco obtížněji bychom tuto metodu vztahovali např́iklad na princip palindromu, který s výchozím textem nepracuje.

\section{Dílna potenciálního překladu}

Překlad je ve své podstatě rovněž vyjádřením potenciality. Jak upozorňuje Martin Ringot, ,jeden výchozí text může být základem pro nepřeberné množství možných překladů a to do té míry, do jaké nemůže verze věrná po všech stránkách existovat" (RINGOT 2014: 271). Stejný názor sdílí i Pablo Martín Ruiz: překlad by podle něj mohl být úplně stejně ve středu zájmu OuLiPo jako 
jím je kreativní psaní, nebot’ obě tyto sféry se vyznačují koncepcí potenciality a tvůrčím zadáním (RUIZ 2016: 924).

Touto tezí se otevírá zcela nový prostor reflexe, kterou v roce 2016 započalo již zmíněné uskupení OuTransPo. Založení Dílny potenciálního překladu se řadí po bok obdobných Ou-X-Po projektů (v oblasti filmu např. působí OuCiPo). Mezinárodní seskupení bilingvních překladatelů, spisovatelů, vědců a hudebníků věnuje svůj čas kreativním přístupům $\mathrm{k}$ překladu, především prostřednictvím virtuálních setkání konaných každý měsíc. Jako každá Ou-X-Po varianta, hodná svého jména, disponuje i OuTransPo soupisem restriktivních zadání, která jsou charakteristická pro vykonávání jejich disciplíny - překladu. Jak již bylo řečeno, překlad s určitou restrikcí pracuje vždy, je to jeho přirozenou součástí. Členové OuTransPo však vymysleli celou řadu dalších dobrovolně zvolených omezení, která překládání proměňují v mnohem zábavnější hru. Například „rebuslation“ spočívá v rozložení výchozího textu na slabiky a jejich následného přeložení jako by se jednalo o samostatná slova. ${ }^{15}$ „Gendertranslation“ je překladem, kdy $\mathrm{v}$ cílovém textu mají všechna substantiva opačný rod než v textu výchozím. ${ }^{16}$ Nakonec, když si podají ruku OuLiPo a OuTransPo, vznikne „hypertranslation“ neboli překlad s určitým zvoleným restriktivním zadáním, jehož výchozí text je rovněž napsaný na základě restriktivního zadání. Vynalézavost, fantazie a snad i odvaha členům OuTransPo neschází. Vedle kreativních projektů se současně řada $\mathrm{z}$ nich zaměřuje $\mathrm{v}$ odborných publikacích na problémy a obecné rysy překladu potenciální literatury.

Představením tvưrčích principů Dílny potenciální literatury jsme nastínili, že se vskutku nejedná o tu překladatelsky nejsnazší literární oblast. Zohledníme-li však, že tento typ literatury překládán je, je namístě se zamyslet na tím, jaký typ překladové strategie se může v tomto kontextu využít. Volný prostor pro reflexi jsme vytvořili již odpoutáním se od tradičního pojmu „překlad“ a nabídnutím alternativ v podobě transkreace, variace a přepisu. Dále jsme konstatovali, že překlad a potenciální literatura mají řadu společných rysů. Obě tyto disciplíny vznikají na základě zadání, a jsou tak obě vyjádřením potenciality. Toto pozorování se jeví jako klíčové Jonathanu Baillehacheovi: „Jestliže lze překlad a potenciální literaturu srovnávat, pak z toho můžeme vyvodit, že překládat literaturu zadání je srovnatelné s psaním literatury zadání v jiném jazyce“"(BAILLEHACHE

15) Francouzské „Joyeux anniversaire Lily“ dá takto vzniknout anglickému „Cheek goose eyes donkey winter deer bed bed“.

16) Zřejmě navrženo pro jazyky disponující (pouze) mužským a ženským rodem. 
2016: 892). Jinými slovy, translát odkazuje nepochybně ke svému výchozímu textu, v případě potenciální literatury však translát odkazuje i k zadání, které mu dává podobu (a toto zadání je čtenáři dokonce blíže než výchozí text). Nebude tím pádem přehnané označit překladatele za jednoho z tvůrců: nezajištuje pouhý jazykový a kulturní přenos, ale je i autorem konkrétní realizace zadání. (1) Způsob, jakým se úkolu zhostí, bude do velké míry odrazem jeho vlastních tvưrčích schopností a preferencí. V první řadě však bude dokladem jeho nezlomné vůle skoncovat s myšlenkou „nepřeložitelnosti“.

\section{PRAMENY}

\section{LE LIONNAIS, François}

1973 „La LiPo. Le premier Manifeste“, in OULIPO, La littérature potentielle : Créations, re-créations, récréations (Paris: Gallimard), s. 15-18

\section{LESCURE, Jean}

1973 „Petite histoire de l'Oulipo“, in OULIPO, La littérature potentielle : Créations, re-créations, récréations (Paris: Gallimard), s. 24-35

\section{OULIPO}

1988 Atlas de littérature potentielle (Paris: Gallimard)

2017 „Oulipiens“, Oulipo. Dostupné z: https://oulipo.net/fr/oulipiens, cit. 16. 11. 2019

2017 „Contraintes“, Oulipo. Dostupné z: https://oulipo.net/fr/contraintes, cit. 16. 11. 2019

OULIPO a BENS, Jacques

2005 Genčse de l'Oulipo : 1960-1963 (Bordeaux: Castor astral)

\section{OUŘEDNÍK, Patrik}

1994 „Poznámka překladatele“, in Queneau, R. Stylistická cvičení (Praha: Volvox Globator), s. 119-121

\section{OUTRANSPO}

2016 „Acts de fundación“, Outranspo. Dostupné z: http://www.outranspo.com/acts-de-fundacion/, cit. 16. 11.2019

2017 „Classification of Translation Constraints \& Procedures“, Outranspo. Dostupné z: http://www.outranspo.com/classification-of-translation-constraints-procedures/, cit. 16. 11. 2019

\section{PEREC, Georges}

1994 La Disparition (Paris: Denoël)

1997 Les revenentes (Paris: Julliard)

2003 Dee Weedergenger, překlad Peter Ronge (Johannes Lang) 
QUENEAU, Raymond

1994 Stylistická cvičení, překlad Patrik Ouředník (Praha: Volvox Globator)

2013 Exercices de style (Paris: Gallimard)

\section{LITERATURA}

BAILLEHACHE, Jonathan

2016 „Traduire la littérature à contraintes : Traduction ou transposition ?“, in MLN , 131(4), s. 892-904

BERMAN, Antoine

1999 La Traduction et la lettre ou l'Auberge du lointain (Paris: Le Seuil)

DE BARY, Cécile

2014 Une nouvelle pratique littéraire en France : Histoire du groupe Oulipo de 1960 à nos jours (Lewiston: Edwin Mellen Press)

KONU゚PEK, Jiří

1966 „Literární kuriozity Raymonda Queneaua“, in Světová literatura. Revue zahraničních literatur, 3, s. 160-174

NORD, Christiane

2008 La traduction, une activité ciblée: introduction aux approches fonctionnalistes (Arras: Artois Presses Université)

2006 Plav - měsičník pro světovou literaturu, roč. 2, č. 10

RĂDULESCU, Valentina

2017 „Contrainte et réécriture-création dans la traduction des Exercices de style de Raymond Queneau“, in Translationes, 9(1), s. 40-54

RUIZ, Pablo Martín

2016 „Ways to Start Looking at Potential Translation“, in MNL, 131(4), s. 919-931

RINGOT, Martin

2014 „Traduction sous contrainte d'un livre mythique: Le cas des Exercices de style de Raymond Queneau ou l'exercice oulipien d’Umberto Eco“, in Cahiers D'études Romanes, 29, s. 269-283

SATTLER-HOVDAR, Nina

2016 Translation - Transkreation: vom Über-Setzen zum Über-Texten (Berlin: BDÜ Fachverlag)

ŠMíDOVÁ, Anna

2019 Aplikace funkcionalistických koncepcí překladu na českou verzi Exercices de style Raymonda Queneaua, magisterská diplomová práce, vedoucí Zbyněk Fišer (Brno: Masarykova univerzita) 
Mgr. Anna Šmídová, 428598@mail.muni.cz, Ústav české literatury, Filozofická fakulta Masarykovy univerzity, Brno, Česká republika / Department of Czech Literature, Faculty of Arts, Masaryk University, Brno, Czech Republic 